Vol. 3, No. 1, 2021

https://doi.org/10.23939/jtbp2021.01.008

Vasyl Iliv, Yarema Iliv

\title{
STUDY OF FLUIDITY AND KINEMATIC VISCOSITY OF ORGANIC SILICONAL LIQUIDS AND MIXTURES BASED ON THEM
}

\author{
Lviv Polytechnic National University, \\ Department of Building Production, \\ vasililiv1960@gmail.com
}

(c) Iliv V., Iliv Ya., 2021

Preliminary studies have shown that hydrophobic materials ZDP "Silicon Polymer" 136-157 M, ETS-32, ETS-40 and a number of their analogues, in contrast to GKZh-11N and GKZh-11K, can withstand excess water pressure of $0.02 \mathrm{MPa}$ when tested for methods developed on the basis of standard methods for determining the water resistance of concrete and tiles. The authors of the article developed experimental waterproofing liquids $1 \mathrm{~K}, 2 \mathrm{~K}, 1 \mathrm{~N}$ and $2 \mathrm{~N}$, based on GKZh-11 $\mathrm{N}$ and GKZh-11 K. These liquids are ready for use for hydrophobization and silicatization of organosilicon compounds. The depth of penetration of waterproofing liquids into wall materials depends, in addition to the absorbency, on the value of the kinematic viscosity of such liquids. Therefore, the establishment of conditional and kinematic viscosity of waterproofing liquids is one of the tasks set in this article. Conditional (fluidity) and kinematic viscosity, due to their relationship, were determined using viscometers VZ-1, VZ-4, VZ-246 and a ball viscometer.

Key words: waterproofing liquids, hydrophobization, silicateization, conditional viscosity (fluidity), kinematic viscosity, viscometer, waterproofing liquids, hydrophobic treatment.

\section{Introduction}

Corrosion processes due to constant contact of the surface of building materials with aggressive environmental factors lead to a gradual deterioration of their decorative and operational properties. To solve this problem, it is necessary to use for structures and materials impregnation with solutions of polymers resistant to chemically aggressive agents and natural factors, especially organosilicon liquids. (Sokolov, Krol, Yepifanova, 2017) Current building codes and regulations stipulate that protection against the negative effects of corrosion is the impregnation of building materials with various polymeric and monomeric compounds that increase the resistance of structures to aggressive influences (Svidersiky, Karavayev, 2010), (Svidersiky, Karavayev, 2012), (Givlyud, Parchomenko, Margal, 2016).

Impregnation of ceramic bricks and stones, porous natural stone, porous concrete with organosilicon compounds of different compositions, especially in the restoration of vertical and horizontal waterproofing in old buildings, houses and technical structures, is a complex diffusion process. It includes the stages of wetting, adsorption, pore filling and diffusion, which occur in different combinations and sequences and depend on the physicochemical properties of the impregnating compositions and the absorbing matrix. One of the most important characteristics of the impregnation depth is the value of the kinematic viscosity index. The greater its numerical value, the smaller the value of the diffusion coefficient, and accordingly, the depth of impregnation with solutions of organosilicon compounds and organosilicon liquids. Since the establishment of kinematic viscosity is a complex, time-consuming process, which, moreover, requires expensive specific equipment, so in practice operate a technological indicator associated with the viscosity fluidity of liquids and call them the viscosity determined mainly, sometimes leaking from the tank of a certain shape and volume (Mukhametrakhimov, 2011) (SNiP 2.03.11-85, 1986). 


\section{Target of this article}

When continuing research work with water-repellent materials produced by SE "Silicon Polymer" and obtained waterproofing fluids based on these products (Iliv, 2006), it is necessary to establish the possibility and conditions of use of such liquids in obtaining or renewing vertical and horizontal waterproofing in old buildings, structures and engineering structures. As mentioned, the depth of their penetration into wall materials depends, in addition to the absorbency, on the value of the kinematic viscosity of such liquids. Therefore, the establishment of such indicators is one of the tasks set in this article.

\section{Research materials}

Hydrophobization of building materials (concrete, limestone, brick) protects them from premature destruction under the influence of atmospheric conditions, and in some cases is a prerequisite for their use. Aqueous solutions of sodium or potassium alkylsiliconate (GKZh-11 H or GKZh-11 K) give good results. And textile materials after hydrophobization do not get wet and do not pass water, however keep permeability to air and water vapor. Water absorption is reduced by about 20 times at a consumption of $1.5-2.5 \%$ of organosilicon compounds by weight of the textile.

Previous studies have shown that liquids GKZh-11 N and GKZh-11 K, as the main impregnating hydrophobic materials of ZDP "Silicon Polymer", do not withstand excess water pressure of $0.02 \mathrm{MPa}$ when tested according to methods developed on the basis of standard methods for determining the water resistance of concrete and skull. But slightly better results were obtained when testing 136-157 M, ETS-32, ETS-40 and a number of their analogues. They became the objects of study of conditional and kinematic viscosity.

Experimental waterproofing liquids $1 \mathrm{~K}, 2 \mathrm{~K}, 1 \mathrm{~N}$ and $2 \mathrm{~N}$ were developed on the basis of watersoluble GKZh-11N and GKZh-11K, which were also subjected to research (Iliv, 2006). The viscosity of the AQUAFIN-F waterproofing fluid manufactured by SCHOMBURG (Germany) was also investigated to obtain a comparative characteristic.

\section{Techniques used}

Viscosity is one of the important and fundamental indicators of liquid consumables. When working with liquids of a certain viscosity (liquid soils and paints, varnishes, gels, etc.), funnel-type viscometers are used to measure the relative viscosity. The value of the viscosity index is determined in seconds as the time during which the liquid flows out of the filled funnel. To determine the viscosity of varnishes and paints and products that are close to them in terms of performance, devices are used viscometers in the form of funnels of special design VZ-1, VZ-4, VZ-246 and ball viscometer (Interstate standard GOST 8420-74) (GOST 9070-75) (Gorshkov, Timashov, Savelev, 1981).

The VZ-1 viscometer (Fig. 1, a) is used to determine the conditional viscosity (leakage time) of paints and similar products - Newtonian or similar liquids (Interstate standard GOST 8420-74) (GOST 9070-75).

The viscometer is a cylindrical tank that passes from the bottom into a hollow cone with a removable nozzle. The nozzle is made of stainless steel. The device is mounted on a tripod with adjustable legs.

Viscometer VZ-4 (Fig. 1, $b$ ) is a device designed to determine the conditional viscosity, (leakage time) of paints and similar products - Newtonian and similar liquids, according to GOST 8420-74 and GOST 9070-75 (Interstate standard GOST 8420-74) (GOST 9070-75). The viscometer of this modification has one fixed nozzle with a diameter of $4 \mathrm{~mm}$. The bowl is made of D16T aluminum alloy (European analogue 2024).

The conditional viscosity is the time of leakage in seconds of a certain volume of the test material through the calibrated nozzle of the viscometer.

The complete set of the VZ-4 viscometer includes: the case of the viscometer; three legs with tips. 
The main technical characteristics of the VZ-4 viscometer are:

- capacity of the tank made according to GOST 9070-75, - $100 \pm 1 \mathrm{~cm}^{3}$;

- diameter of the nozzle $-4 \pm 0.015 \mathrm{~mm}$;

- nozzle height $-4 \pm 0.05 \mathrm{~mm}$;

- temperature of the controlled solution $-20 \pm 0.5^{\circ} \mathrm{C}$;

The device "Viscometer VZ-246" (Fig. 1, b) is designed to quickly determine the conditional viscosity (leakage time) of paints and similar products - Newtonian or similar liquids in accordance with GOST 9070-75 (Interstate standard GOST 8420-74) (GOST 9070-75)..

The VZ-246 viscometer is a funnel-shaped tank with three interchangeable nozzles with a diameter of 2, 4 and $6 \mathrm{~mm}$. When equipped with only one nozzle per $4 \mathrm{~mm}$, such a viscometer is called Viscometer VZ-4 specified in the name or description of GOST 9070-75, but the name "VZ-4" in this GOST is missing.

The higher the viscosity of the test fluid, the larger the diameter of the nozzle used. The principle of operation of the viscometer is based on determining the time of leakage of a certain volume of test fluid through the nozzle hole. The bowl of the viscometer is filled with the test liquid (eg paint), open the nozzle and record the time before the first interruption of the liquid jet.

The main technical characteristics of the VZ-246 viscometer are:

- capacity of the tank made according to GOST 9070-75, $-100 \pm 1 \mathrm{~cm}^{3}$;

- nozzle diameters $-2.000 \pm 0.012 \mathrm{~mm} ; 4.000 \pm 0.015 \mathrm{~mm} ; 6.000 \pm 0.015 \mathrm{~mm}$;

- nozzle height, $\mathrm{h}, \mathrm{mm}, 4.000 \pm 0.015 \mathrm{~mm}$;

- the range of liquid leakage time is for a nozzle with a diameter of $2 \mathrm{~mm} 70-300 \mathrm{sec}$, , for a nozzle $4 \mathrm{~mm}-12-200 \mathrm{~s}$ and for a nozzle of $6 \mathrm{~mm}-20-200 \mathrm{~s}$;

- the limit of the value of the main relative error of measuring the end time of the calibration fluid (industrial oil with a nominal value of kinematic viscosity from 200 to $500 \mathrm{~mm} / \mathrm{s}$ ) not more than $\pm 3 \%$ of the arithmetic mean time;

- overall dimensions of the viscometer (without tripod) are: diameter $50 \mathrm{~mm}$. height $68 \mathrm{~mm}$.

Ball viscometer (Fig. 1,c) is a glass tube 3, the lower end of which is closed by a stopper 1 , complete with a steel ball 4 with a diameter of $7.938 \mathrm{~mm}$ according to GOST 3722 (Interstate standard GOST 8420-74) (GOST 9070-75)..

The glass tube has a length of $350 \mathrm{~mm}$ and a diameter of $20 \mathrm{~mm}$ with the marks 2 and 5, the distance between which is $250 \mathrm{~mm}$, and is vertically reinforced in the tripod 6 .

Determination of conditional viscosity by viscometer VZ-1

Water is poured into the bath of the viscometer to maintain the temperature of the test material $(20 \pm 0.5)^{\circ} \mathrm{C}$, close the nozzle with a rod and pour the test material into the inner tank to the level of the hook tip; using the adjusting screws of the tripod, the viscometer is set so that all three tips of the hooks are in the same plane and are barely visible on the surface of the test material. The inner tank is closed with a lid, into the hole of which a thermometer is inserted, a beaker is placed under the nozzle of the viscometer. After raising the air bubbles on the surface of the test material and at its temperature $(20 \pm 0.5){ }^{\circ} \mathrm{C}$ quickly remove the rod, simultaneously with the appearance of the test material from the nozzle of the viscometer turn on the stopwatch. When the test material in the beakers reaches exactly the level of the mark of $50 \mathrm{~cm}$, the stopwatch is stopped and the end time is counted with an error of not more than $0.2 \mathrm{~s}$ (Interstate standard GOST 8420-74) (GOST 9070-75).

The viscometer is placed in a tripod and with a level set in a horizontal position. A vessel is placed under the viscometer nozzle. The nozzle hole is closed with a finger, the test material is poured into the viscometer in excess to form a convex meniscus over the upper edge of the viscometer. Fill the viscometer slowly to prevent air bubbles. Excess material and the formed air bubbles are removed using a glass plate or aluminum disk, shifted along the upper edge of the funnel in the horizontal direction so as not to form an air layer. 
Determination of conditional viscosity by viscometer type VZ-246 and VZ-4

Open the nozzle hole and simultaneously with the appearance of the test material from the nozzle turn on the stopwatch. At the time of the first interruption of the jet of the test material, the stopwatch is stopped and the end time is counted (Interstate standard GOST 8420-74) (GOST 9070-75).

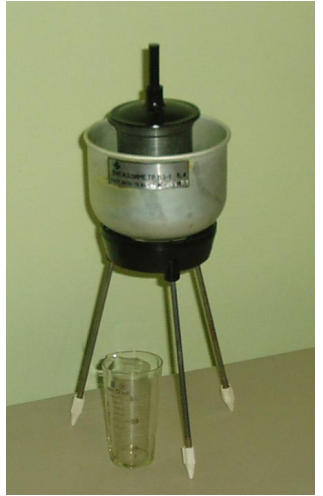

$a$

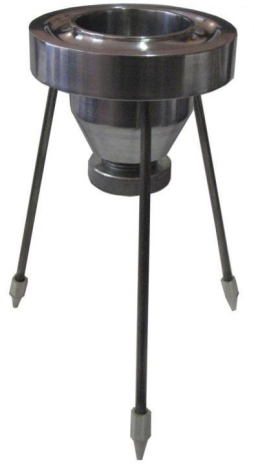

$b$

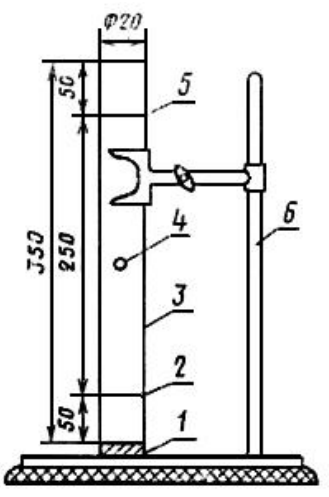

$c$

Fig. 1. General view and drawings of viscometers:

$a-G e n e r a l$ view of the viscometer VZ-1; $b$ - General view of the viscometer VZ-4 and VZ-246;

c-Ball viscometer: 1 -cork; 2 -lower label; 3 -tube; 4 -ball; 5 - upper label; 6-tripod.

Determination of conditional viscosity by a ball viscometer

The glass tube of the viscometer is installed vertically and filled with the test material $1-2 \mathrm{~cm}$ above the upper mark. In the case of air bubbles, they are removed with a glass rod after lifting to the surface. Then freely lower the steel ball into the center of the tube and at the time of reaching the lower edge of the ball of the upper mark include a stopwatch. When the ball reaches the lower edge of the lower mark of the tube, the stopwatch is stopped and the time of passage of the ball in seconds between the two marks of the tube of the viscometer with an error of not more than $0.2 \mathrm{~s}$ (Interstate standard GOST 8420-74) (GOST 9070-75).

Determination of conditional viscosity in all types of viscometers is carried out at least three times. Repeated measurements are performed immediately after the end of the previous one (without cleaning the viscometer) by filling a new portion of the test material. At the end of the measurement, the viscometer is thoroughly cleaned with solvent, especially carefully cleaning the nozzle to prevent damage.

The test result is the arithmetic mean of the results of at least three end-time measurements in seconds.

For viscometers types VZ-1 and VZ-4 conditional viscosity is calculated by the formula:

$$
X=t \cdot K \text {, }
$$

where $t$ - the arithmetic mean of the end time of the test material, $\mathrm{s} ; K$ - the correction factor of the viscometer.

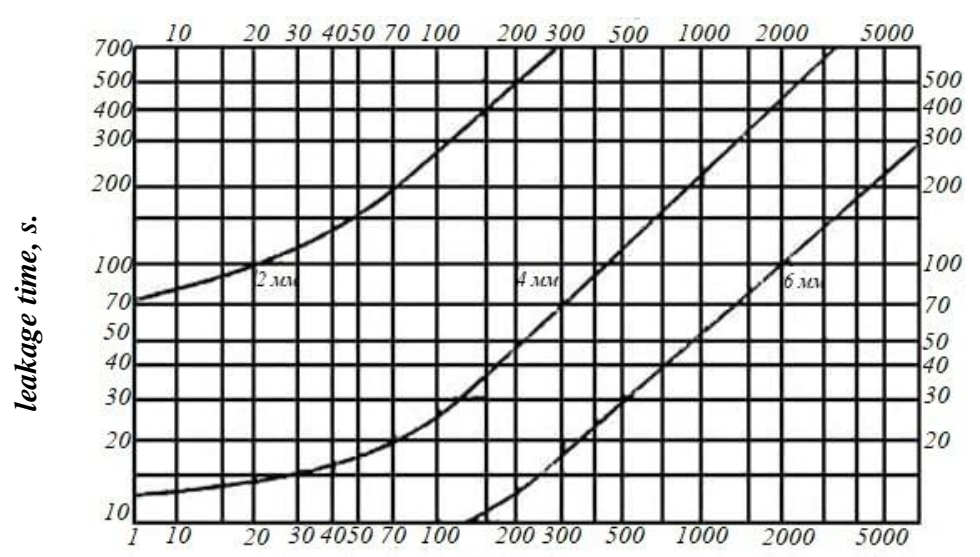

Kinematic viscosity, $\mathrm{mm}^{2} / \mathrm{s}$

Fig. 2. Dependence of leakage time on the viscosity of liquid materials 
Permissible deviations of separate definitions of end time from arithmetic mean value at carrying out of test by one executor should not exceed $\pm 3 \%$, at carrying out of test by various executors $\pm 5 \%$.

The test result is the arithmetic mean of the three measurements of the leakage time of the test fluid.

The absolute error of measuring the time (c) of fluid leakage is calculated by the formula:

$$
\Delta=\mathrm{t}_{\mathrm{B}}-(0,185 \cdot \mathrm{v}+10),
$$

where $t_{\mathbf{B}}$ - the arithmetic mean of the end time of the test fluid, sek.; $v$ - the kinematic viscosity of the test fluid, which is determined according to GOST 33-82 at a temperature of $(20 \pm 0.2)^{\circ} \mathrm{C}, \mathrm{mm}^{2} / \mathrm{s}$.

\section{Results of the research}

Specific rheological properties that affect the permeability of organosilicon fluids to building materials include their conditional viscosity, expressed as fluidity, and the associated kinematic viscosity. Materials with a high value of kinematic viscosity (respectively fluidity) penetrate to a shallower depth into building materials, so they achieve a less effective hydrophobic effect (Demidchuk, 2012) (Demidchuk, Givlyud, Fedun, 2012).

Fluidity and kinematic viscosity, due to their relationship, were determined using viscometers VZ-1, VZ-4, VZ-246 and a ball viscometer. The test results are shown in Table 1.

Table 1

Values of conditional viscosity (fluidity) and kinematic viscosity of waterproofing liquids

\begin{tabular}{|c|l|c|c|c|c|c|}
\hline \multirow{2}{*}{$\begin{array}{c}\text { No. } \\
\text { i/o }\end{array}$} & \multicolumn{1}{|c|}{ Material } & \multicolumn{4}{|c|}{ Value of conditional viscosity (fluidity), s } & \multirow{2}{*}{$\begin{array}{c}\text { Kinematic viscosity, } \\
\mathrm{mm}^{2} / \mathrm{s}\end{array}$} \\
\cline { 3 - 6 } & VZ-1 & VZ-4 & VZ-246 & $\begin{array}{c}\text { Ball } \\
\text { viscometer }\end{array}$ & 1.02 \\
\hline 1 & Mixture 1 K & 12.4 & 8.5 & 64.2 & 6.7 & 2.03 \\
\hline 2 & Mixture2 K & 12.9 & 8.7 & 66.8 & 6.9 & 2.28 \\
\hline 3 & Mixture 1 N & 13.8 & 9.2 & 71.5 & 7.7 & 1.03 \\
\hline 4 & Mixture 2 N & 13.0 & 8.7 & 67.3 & 7.2 & 8.07 \\
\hline 5 & $\begin{array}{l}\text { Microemulsion } \\
\text { 136-157M (6\%) }\end{array}$ & 14.0 & 9.4 & 69.8 & 7.8 & 23.6 \\
\hline 6 & ETS-32 & 15.2 & 10.2 & 78.6 & 8.5 & 20.3 \\
\hline 7 & ACOR B-100 & 14.8 & 9.9 & 74.7 & 8.4 & 1.02 \\
\hline 8 & AQUAFIN-F & 12.6 & 8.5 & 65.2 & 7.1 & \\
\hline
\end{tabular}

As can be seen from the above results, all developed water-soluble test mixtures, as well as AQUAFIN-F, have relatively low values of conditional viscosity (fluidity) and accordingly the kinematic viscosity, which makes their use successful in the arrangement or restoration of horizontal and vertical waterproofing. It should be noted that waterproofing fluids based on GKZh-11K (mixtures of $1 \mathrm{~K}$ and $2 \mathrm{~N}$ ) have a slightly lower value of conditional viscosity (fluidity) and kinematic viscosity compared to liquids based on GKZh-11N (a mixture of $2 \mathrm{~K}$ and $1 \mathrm{H}$ ), but their values are co-dimensional with the values of conditional and kinematic viscosity of AQUAFIN-F.

It was also found that water-insoluble or partially water-soluble organosilicon liquids $(6 \%$ microemulsion 136-157 M, ETS-32, ACOR B-100) have a slightly higher value of conditional viscosity (fluidity). However, due to their nonlinear dependence with kinematic viscosity, they have much higher values of the latter indicator, which complicates their application. Among them, the lowest value of conditional and kinematic viscosity has $6 \%$ microemulsion 136-157 M. Its kinematic viscosity is 3.5-7.9 times lower than water-soluble mixtures. For ETS-32 and ACOR B-100 the values of conditional viscosity (fluidity) are 1.11 and 1.09 times higher compared to the microemulsion 136-157 M, which causes a significant increase in the value of kinematic viscosity of 2.92 and 2.52 times. 


\section{Conclusions}

1. Developed water-soluble test mixtures, as well as AQUAFIN-F, have the advantage of use in the installation or restoration of horizontal and vertical waterproofing, because they have a lower value of conditional and kinematic viscosity (Iliv, Givlyud, Iliv, 2015) (Iliv, Iliv, 2017) (Iliv, Iliv, 2018).

2. Microemulsion $136-157 \mathrm{M}$ at $6 \%$ concentration has a slightly lower permeability compared to the developed water-soluble mixtures, but its use in the arrangement or restoration of horizontal and vertical waterproofing is acceptable (Iliv, Iliv, 2017) (Iliv, Iliv, 2018).

3. ETS-32 and ACOR B-100 have limited use as waterproofing fluids due to the high value of conditional and kinematic viscosity and, accordingly, reduced permeability to porous building materials.

\section{References}

Sokolov, V. I., Krol, O. S, Yepifanova, O. I. (2017). Hydraulics. Publishing house of the West Ukrainian National University. Severodonezk. P. 160. (in Ukrainian).

Svidersiky, V. A., Karavayev, T. A. (2010). Status, structure and protects development of the paint and varnish industry of Ukraine. Paint and varnish materials and their application. P. 8-16. (in Russian).

Svidersiky, V. A., Karavayev, T.A. (2012). Aesthetic properties of coatings from water-dissert paints. Goods and markets. P. 181-190. (in Ukrainian).

Givlyud, M. M., Parchomeko, V-P. O., Margal, I. V. (2016). Influense of hydrophobic protective coatings of the durability of concrete construction. Collection of scientific works of LNTU of Ukrainian. Lviv. Vol. 26.3. P. 311-316 (in Ukrainian).

Mukhametrakhimov, R. H. (2011). Investigation of the influence of organosilicon compounds on the properties of fiber cement boards. R. H. Mukhametrakhimov, V. S. Izotov. Izvestiya KGASU, No. 4 (18). P. 254258 (in Russian).

Protection of building structures against corrosion. (1986): SNiP 2.03.11-85. M, Stroyizdat, 1986. P. 48 (in Russian).

Iliv V. V. (2006). Reception of high-performance waterproofing materials on the basis of domestic raw materials. Theory and practice of construction. Proceedings of the National University Lviv Polytechnic. Lviv. Vol. 545. P. 79-82 (in Ukrainian).

Gorshkov, G. S., Timashov, V. V., Savelev, V. G. (1981). Methods of physical and chemical analysis of binders. M. Higher school, 335. P. 73 (in Russian).

Demidchuk, L. B. (2012). Complex assessment of operational properties of protective coatings of building structural materials. Scientific. spring NLTU of Ukraine. No. 22.3. P. 118-122 (in Ukrainian).

Demidchuk, L B., Givlyud, M. M., Fedun, B. V. (2012). Ways to increase the durability of concrete structures with hydrophobic protective coatings. Commodity Bulletin. No. 5. P. 51-56 (in Ukrainian).

Iliv, V. V., Givlyud, M. M., Iliv, Ya. V. (2015). Features of the use of waterproofing materials based on silicone substances. Theory and practice of construction. Proceedings of the National University Lviv Polytechnic. Lviv. Vol. 823. P. 129-135 (in Ukrainian).

Iliv, V. V., Iliv, Ya. V. (2017). Features of the use of organosilicon substances as materials for obtaining vertical waterproofing of walls. Theory and practice of construction. Proceedings of the National University Lviv Polytechnic. Lviv. Vol. 877. P. 94-100 (in Ukrainian).

Iliv, V. V., Iliv, Ya. V. (2018). Investigation of the Permeability of Organosilicon Liquids into Materials for Vertical and Horizontal Waterproofing of Walls. Theory and practice of construction. Proceedings of the National University Lviv Polytechnic. Lviv. Vol. 888. P. 65-72 (in Ukrainian). 
В. В. Ілів, Я. В. Ілів

Національний університет “Львівська політехніка", кафедра будівельного виробництва

\section{ДОСЛІДЖЕННЯ ТЕКУЧОСТІ ТА КІНЕМАТИЧНОЇ В'ЯЗКОСТІ КРЕМНІЙОРГАНІЧНИХ РІДИН ТА СУМІШЕЙ НА ЇХ ОСНОВІ}

(C) Ілів В. В., Ілів Я. В., 2021

Дослідженнями встановлено, що гідрофобні матеріали ЗДП “Кремнійполімер" 136-157 М, ETC-32, ЕTC-40 та деякі ї аналоги, на відміну від ГКЖ-11Н і ГКЖ-11К, витримують надлишковий тиск води 0,02 МПа під час випробувань за методиками, подібними до методик визначення водонепроникності бетонів та черепиці. Автори на основі ГКЖ-11Н і ГКЖ-11К розроблено гідроізолюючі рідини 1 К, 2 К, 1 Н та 2 Н. Вони гідрофобізують і звужують чи перекривають капіляри в бетоні, цегляній і кам'яній кладці. Перекриття капілярної структури зумовлене взаємодією 3 вапном чи солями з утворенням нерозчинних сполук, які припиняють капілярне всмоктування. Глибина проникнення цих рідин у стінові матеріали залежить, крім поглинальної здатності, від значення кінематичної в'язкості таких рідин. Тому встановлення умовної та кінематичної в'язкості гідроізолюючих рідин завдання, поставлене у статті. Умовну (текучість) та кінематичну в'язкість, через їх взасмозв'язок, визначали віскозиметрами В3-1, В3-4, В3-246 та кульковим віскозиметром. Для отримання порівняльної характеристики досліджували гідроізолюючу рідину AQUAFIN-F виробництва SCHOMBURG (Німеччина).

Як видно із наведених результатів, у всіх розроблених водорозчинних сумішей, як і AQUAFIN-F, достатньо низькі значення умовної в'язкості (текучості) i, відповідно, кінематичної в’язкості, що дає змогу їх застосувати під час виконання чи відновлення гідроізоляції.

Зауважимо, що водонерозчинні чи частково водорозчинні кремнійорганічні рідини (6 \% мікроемульсія 136-157М, ЕТС-32, АКОР Б-100) мають дещо більше значення умовної в' язкості (текучості), а через нелінійну їх залежність від кінематичної в'язкості, їм властиві значно більші значення останнього показника, що ускладнює їх застосування.

Ключові слова: гідроізолюючі рідини, гідрофобізація, силікатизація, умовна в'язкість (текучість), кінематична в'язкість, віскозиметр, гідроізоляційні рідини, гідрофобна обробка. 